\title{
Evaluation of Cherry Tomato (Solanum lycopersicum var. cerasiforme) Genotypes for Yield and Quality Traits
}

\author{
M. H. Najeema*, Revanappa, H. P. Hadimani and I. B. Biradar \\ Department of Vegetable science, College of Horticulture, Bagalkot, University of \\ Horticultural Sciences, Udyanagiri, Bagalkot-587104, Karnataka, India \\ *Corresponding author
}

\section{A B S T R A C T}

\begin{tabular}{|l|}
\hline Ke y w or d s \\
$\begin{array}{l}\text { Cherry tomato, growth, } \\
\text { yield, quality and } \\
\text { evaluation }\end{array}$ \\
\hline Article Info \\
\hline $\begin{array}{l}\text { Accepted: } \\
\text { 20 May } 2018 \\
\text { Available Online: } \\
\text { 10 June } 2018\end{array}$ \\
\hline
\end{tabular}

\section{Introduction}

Cherry tomato (Solanum lycopersicum var. cerasiforme) is a botanical variety of the cultivated tomato. It is thought to be the ancestor of all cultivated tomatoes. It has become more popular all over the world because of a good source of vitamins A and C, solids content, good taste and fruit set even at high temperature (Prema et al., 2011). It is marketed at a premium to ordinary tomatoes. Cherry tomatoes are widely cultivated in Central America and are distributed in California, Korea, Germany, Mexico and Florida. It is a warm season crop, reasonably tolerant to heat and drought and grows under wide range of soil and climatic conditions
The present study was carried out to know the performance of cherry tomato genotypes for different traits attributing for growth, yield and quality in cherry tomato at the Division of Vegetable Crops College of Horticulture, Bagalkot (Karnataka), India during the period between September 2015 to February 2016. Among the genotypes used for investigation BCT-8 showed highest plant height $(126.20 \mathrm{~cm})$, highest number of primary $(6.3)$ and secondary branches (13.5) and highest yield per plant in (1779.6g). Highest TSS was (8.02 $\left.{ }^{\circ} \mathrm{B}\right)$ Maximum $\mathrm{pH}$ of fruit juice was noticed in BCT-25 (4.34). (BChe content in fruits was ranged from 0.91 (BCT-1) to $6.20 \mathrm{mg} / 100 \mathrm{~g}$ (BCT-24) Ascorbic acid content was significantly higher in BCT-3 $(34.97 \mathrm{mg} / 100 \mathrm{~g})$. The lycopene content was found maximum in BCT-6 (10.14 mg/100g).

(Anon, 2009a). Cherry tomato is grown for its edible fruits; they are perfect for making processed products like sauce, soup, ketchup, puree, curries, paste, powder, rasam and sandwich. They also have good nutritional and antioxidant properties. The size of cherry tomatoes range from thumb tip to the size of a golf ball. And can range from being spherical to slightly oblong in shape (Anon, 2009b). The possible exploitation of hybrid vigour in cherry tomato has been taken up at few research centres however very little systematic attention has been paid by plant breeders to study performance for yield and its components in cherry tomato. The genotypes performing well can be used further in heterosis breeding programme. 


\section{Materials and Methods}

The investigation was carried out during rabi season of 2015-16 at the experimental block of the Department of Vegetable Science, College of Horticulture, Bagalkot. The experimental field is situated in the Northern Dry Zone (Zone 3) of Karnataka, located at $75^{0} 36^{\prime}$ East longitude and $16^{\circ} 09^{\prime}$ North latitude and at an altitude of $536.75 \mathrm{~m}$ above Mean Sea Level (MSL). The experimental material comprised of 30 cherry tomato genotypes collected from KRC College of Horticulture, Arabhavi.

\section{Nursery techniques}

Cherry tomato seeds were sown during September 2015 in plastic pro-trays having 98 cells. Regular irrigation and plant protection measures were taken to raise the good quality seedlings using growing media i.e. mixture of coco peat and farm yard manure in 2:1 ratio and plant protection measures were carried out. During October 2015, the four week old seedlings were transplanted at the spacing of $60 \mathrm{~cm} \times 45 \mathrm{~cm}$. with 2 replications.

\section{Preparation of experimental plot}

During October 2015, experimental plot was brought to fine tilth by ploughing and harrowing and farm yard manure ( 25 tons/ha) was incorporated to the soil. Plants were nourished with recommended dose of NPK at 115:100:60 kg/ha. All the other recommended cultivation practices were followed as per the POP of UHS, Bagalkot (Anon., 2013). The 30 genotypes were assigned to different rows in each replication by using random table. Simultaneously, all the varieties were transplanted in the main field with spacing of $60 \times 45 \mathrm{~cm}$. The experimental plot was kept free of weeds by hand weeding once in 30 days. Two prophylactic sprays to check the fungal diseases like Alternaria blight etc. Four weeks after transplanting staking was done. Irrigation was provided at weekly intervals considering the rainy days during cropping period. Observations on five randomly selected plants were recorded for various growth, yield and quality attributing traits to see the performance of cherry tomato genotypes.

\section{Biochemical analysis}

The genotypes were analyzed for different quality attributes. The $\mathrm{pH}$ of the product was determined by using a digital $\mathrm{pH}$ meter having combined electrode as described by Jackson (1973). TSS of fruits was measured by using 'Erma' make hand refractometer and expressed as ${ }^{\circ}$ brix after making necessary temperature corrections to the recorded readings. Ascorbic acid content was determined as per AOAC (1984) method using 2, 6-dichlorophenol indophenol dye. Lycopene content of fruits was estimated through the procedure given by Sadashivam and Manickam (1992). $\beta$-carotene content of known weight of fruit sample was extracted using 80 per acetone and sodium sulphate crystals. Further, treated with petroleum ether to obtain clear yellow colour solution. The intensity of colour (OD) was measured at 452 $\mathrm{nm}$ using UV-Visible spectrophotometer (AOAC, 2004) (Madan et al., 2011).

\section{Statistical analysis}

For statistical analysis Randomized Complete Block Design was adopted.

\section{Results and Discussion}

Highest plant height was observed significantly higher in BCT-8 $(126.20 \mathrm{~cm})$ whereas BCT-15 had recorded the lowest plant height. For the character number of primary and secondary branches per plant, it ranged from 4.1 (BCT-19) to 6.3 (BCT-8) and 
7.5 to 13.5 among the genotypes (table 1). More number of branches results in more production of leaves, the size of the leaf and number of leaves per plant decides the efficiency of photosynthesis activity which contributed towards better growth and yield the results were in confirmation with Prema et al., (2011) and Renuka et al., (2014).

There was a significant difference for Number of flowers per cluster, number of fruits per cluster and per cent fruit set in thirty genotypes evaluated (Table 1). Number of flowers per cluster was found significantly higher in BCT-8 (9.72) and minimum number of flower per cluster was observed in BCT-21 (4.86). The maximum number of fruits per cluster was recorded in BCT-8 (7.52), followed by BCT-12 (7.24) and BCT-9 (6.4).

The minimum number of fruits per cluster (3.4) was found in BCT-30. Maximum fruit set $(100 \%)$ was recorded in BCT-24 followed by BCT-22 (85.76\%). The least per cent fruit set was observed in BCT-3 (54.5\%). The increased fruit set might be due to higher rate of anther dehiscence, higher pollen viability; similar results were also reported by Arun et al., (2004) and Prema et al., (2011).

The variation among treatments varied significantly with respect to average fruit weight, number of fruits per plant and fruit yield per plant. Average fruit weight was found significantly higher in BCT-4 (11.84 g) and BCT-18 (11.34 g) followed by BCT-29 (10.95 g) and BCT-11 (10.67 g) and lowest fruit weight was recorded in BCT-24 (1.99 g). Maximum number of fruits per plant was observed in BCT-8 (270.60) followed by BCT-12 (224.10) and BCT-24 (184.60) and minimum was recorded in BCT-15 (133.00), BCT-19 (136.00) and BCT-7 (137.50). The highest fruit yield per plant was recorded in BCT-8 (1779.6g) which was significantly higher than the all other genotypes evaluated.
Similarly, other genotypes like BCT-29, BCT11, BCT-18 and BCT-28 BCT-27 BCT-26 BCT-17 (1561.6g, 1555.6g, 1541.8g, 1494.6g, $1480.9 \mathrm{~g}, 1448.5 \mathrm{~g}$ and $1427.4 \mathrm{~g}$, respectively) also contributed in higher fruit yield per plant but significantly lower than the genotype BCT-8. However, the genotype BCT-24 contributed lowest fruit yield per plant (367.4g). Higher yield of BCT-8 was mainly due to more number of fruits per plant as well as more number of flowers and fruits per cluster in addition to comparatively more number of primary, secondary branches and plant height. The results reported by Shivanand (2008) in tomato where they also opined that the highest yield was due to highest number of fruits per plant supports the present findings.

Tomato ranks first among processed vegetables in the world. The cherry tomato developed for fresh market and processing should have distinct quality characteristics. For processing and fresh market consumption, fruit should be firm, well coloured with acceptable flavour. High total soluble solids (TSS) and low acidity are the major factors considered for manufacture of processed products. One percent increase in TSS content of fruits result in 20 percent increase in recovery of processed product (Berry et al., 1988 and Shivanand, 2008). In the present investigation, the Highest TSS was registered in BCT-27 $\left(8.02^{\circ} \mathrm{B}\right)$ and lowest was observed in BCT-5 (4.89 $\left.{ }^{0} \mathrm{~B}\right)$, respectively. This is in agreement with studies conducted by the earlier workers like Sucheta et al., 2004 in tomato and John et al., 2005 in cherry tomato. Maximum $\mathrm{pH}$ of fruit juice was noticed in BCT-25 (4.34) and minimum was in BCT-5 (3.74). It was found that 4.11 was an average $\mathrm{pH}$ of the fruit juice. Shoba and Arumugam (1991) had also observed a $\mathrm{pH}$ range of 3.12-4.38. Beta-carotene content in fruits was ranged from 0.91 (BCT-1) to 6.20 $\mathrm{mg} / 100 \mathrm{~g}$ (BCT-24). 
Table.1 Evaluation of cherry tomato genotypes for growth and yield parameters

\begin{tabular}{|c|c|c|c|c|c|c|c|c|c|c|}
\hline Sl. No. & Genotypes & $\begin{array}{l}\text { Plant } \\
\text { height (cm) }\end{array}$ & $\begin{array}{l}\text { No. of primary } \\
\text { branches }\end{array}$ & $\begin{array}{l}\text { No. of secondary } \\
\text { branches }\end{array}$ & $\begin{array}{l}\text { Flower } \\
\text { cluster }\end{array}$ & $\begin{array}{l}\text { Fruit / } \\
\text { cluster }\end{array}$ & $\begin{array}{l}\text { Per cent } \\
\text { fruit set }\end{array}$ & $\begin{array}{l}\text { Number of } \\
\text { fruits }\end{array}$ & $\begin{array}{l}\text { Average fruit } \\
\text { weight (g) }\end{array}$ & $\begin{array}{l}\text { Yield } \\
\text { (g) }\end{array}$ \\
\hline 1 & BCT-1 & 82.90 & 5.1 & 7.9 & 6.18 & 3.86 & 62.36 & 148.70 & 6.97 & 1092 \\
\hline 2 & BCT-2 & 102.50 & 4.8 & 9.1 & 6.45 & 4.02 & 62.78 & 144.00 & 5.14 & 753 \\
\hline 3 & ВСТ-3 & 83.70 & 4.9 & 8.1 & 6.42 & 3.48 & 54.5 & 171.80 & 5.26 & 919 \\
\hline 4 & ВCТ-4 & 99.70 & 4.3 & 8.8 & 6.44 & 3.98 & 60.52 & 147.50 & 11.84 & 1388 \\
\hline 5 & ВСТ-5 & 104.70 & 4.4 & 9.7 & 6.86 & 4.80 & 70.39 & 173.40 & 7.00 & 1130 \\
\hline 6 & ВCT-6 & 84.40 & 4.2 & 8.9 & 6.82 & 4.16 & 60.96 & 155.70 & 8.51 & 1258 \\
\hline 7 & ВСТ-7 & 102.00 & 4.7 & 9.4 & 6.62 & 3.96 & 60.11 & 137.50 & 6.79 & 938 \\
\hline 8 & BCT-8 & 126.20 & 6.3 & 13.5 & 9.72 & 7.52 & 77.31 & 270.60 & 6.24 & 1779 \\
\hline 9 & ВСТ-9 & 96.90 & 5.5 & 9.6 & 9.34 & 6.40 & 68.62 & 173.10 & 7.41 & 1227 \\
\hline 10 & ВСТ-10 & 90.40 & 4.3 & 9.8 & 8.54 & 5.66 & 66.26 & 156.20 & 5.35 & 845 \\
\hline 11 & ВСТ-11 & 110.20 & 4.6 & 9.7 & 6.94 & 4.30 & 61.76 & 155.40 & 10.67 & 1555 \\
\hline 12 & ВCT-12 & 99.30 & 5.9 & 11.6 & 9.26 & 7.24 & 78.34 & 224.10 & 5.31 & 1276 \\
\hline 13 & ВCT-13 & 94.60 & 4.7 & 8.5 & 7.06 & 4.64 & 65.53 & 152.80 & 6.77 & 947 \\
\hline 14 & ВСТ-14 & 100.60 & 5.2 & 9.9 & 7.30 & 5.00 & 68.97 & 159.30 & 4.97 & 802 \\
\hline 15 & ВCT-15 & 82.70 & 4.5 & 7.5 & 6.78 & 4.18 & 60.3 & 133.00 & 6.23 & 833 \\
\hline 16 & ВСТ-16 & 88.40 & 4.9 & 9.5 & 8.64 & 5.92 & 68.57 & 149.80 & 5.55 & 822 \\
\hline 17 & ВCT-17 & 89.53 & 4.4 & 8.9 & 5.70 & 3.46 & 60.91 & 149.70 & 10.01 & 1427 \\
\hline 18 & ВCТ-18 & 111.90 & 4.6 & 9.3 & 6.26 & 3.94 & 63.26 & 149.10 & 11.34 & 1541 \\
\hline 19 & ВСТ-19 & 100.60 & 4.1 & 9.4 & 5.94 & 3.90 & 65.74 & 136.00 & 5.96 & 810 \\
\hline 20 & ВСТ-20 & 92.30 & 4.5 & 8.1 & 7.54 & 4.62 & 60.86 & 150.60 & 7.52 & 1103 \\
\hline 21 & ВСТ-21 & 99.30 & 4.5 & 9.4 & 4.86 & 3.66 & 74.97 & 158.90 & 8.29 & 1294 \\
\hline 22 & ВСТ-22 & 91.90 & 4.2 & 8.8 & 5.38 & 4.64 & 85.76 & 161.30 & 6.77 & 1111 \\
\hline 23 & ВCT-23 & 90.40 & 5 & 9.2 & 5.78 & 3.72 & 63.93 & 156.90 & 7.84 & 1203 \\
\hline 24 & ВСТ-24 & 119.30 & 4.9 & 11.2 & 5.44 & 5.44 & 100.00 & 184.60 & 1.99 & 367 \\
\hline 25 & ВCТ-25 & 97.20 & 5.2 & 9.2 & 5.98 & 4.30 & 72.19 & 166.80 & 7.10 & 1168 \\
\hline 26 & ВСТ-26 & 108.40 & 5.0 & 9.5 & 5.92 & 3.62 & 61.25 & 171.60 & 8.83 & 1448 \\
\hline 27 & ВСТ-27 & 110.90 & 4.8 & 9.7 & 6.74 & 4.94 & 73.06 & 152.10 & 9.98 & 1480 \\
\hline 28 & ВСТ-28 & 97.10 & 5.4 & 9.7 & 5.86 & 3.64 & 62.29 & 167.40 & 9.7 & 1494 \\
\hline 29 & ВСТ-29 & 107.70 & 4.7 & 10.1 & 5.34 & 3.56 & 66.54 & 155.10 & 10.95 & 1561 \\
\hline \multirow[t]{4}{*}{30} & ВСТ-30 & 109.70 & 5.3 & 8.9 & 5.34 & 3.40 & 63.68 & 167.00 & 8.10 & 1153 \\
\hline & S.Em \pm & 2.95 & 0.22 & 0.43 & 0.42 & 0.35 & 3.46 & 7.92 & 0.19 & 67.63 \\
\hline & $\mathrm{CD}(0.05$ & 8.54 & 0.64 & 1.23 & 1.21 & 1.01 & 10.02 & 22.90 & 0.55 & 195.62 \\
\hline & CV \% & 4.21 & 6.46 & 6.38 & 8.82 & 10.84 & 7.27 & 6.88 & 3.59 & 8.26 \\
\hline
\end{tabular}


Table.2 Evaluation of Cherry tomato genotypes for quality traits

\begin{tabular}{|l|l|l|l|c|c|c|}
\hline SI. No. & Genotypes & $\begin{array}{c}\text { TSS } \\
\left({ }^{\mathbf{B r i x}}\right)\end{array}$ & $\mathbf{p H}$ & $\begin{array}{c}\text { Betacarotene } \\
(\mathbf{m g} / \mathbf{1 0 0 g})\end{array}$ & $\begin{array}{c}\text { Ascorbic acid } \\
(\mathbf{m g} / \mathbf{1 0 0 g})\end{array}$ & $\begin{array}{c}\text { Lycopene } \\
(\mathbf{m g} / \mathbf{1 0 0})\end{array}$ \\
\hline $\mathbf{1}$ & BCT-1 & 6.37 & 4.25 & 0.91 & 19.29 & 9.13 \\
\hline $\mathbf{2}$ & BCT-2 & 7.19 & 4.01 & 3.48 & 24.64 & 8.74 \\
\hline $\mathbf{3}$ & BCT-3 & 5.86 & 3.86 & 4.17 & 34.97 & 2.11 \\
\hline $\mathbf{4}$ & BCT-4 & 6.51 & 3.89 & 3.31 & 25.32 & 3.37 \\
\hline $\mathbf{5}$ & BCT-5 & 4.89 & 3.74 & 4.90 & 23.47 & 2.98 \\
\hline $\mathbf{6}$ & BCT-6 & 5.54 & 4.09 & 1.93 & 18.42 & 10.14 \\
\hline $\mathbf{7}$ & BCT-7 & 6.13 & 4.12 & 2.54 & 16.76 & 6.04 \\
\hline $\mathbf{8}$ & BCT-8 & 7.43 & 4.29 & 4.20 & 18.12 & 9.56 \\
\hline $\mathbf{9}$ & BCT-9 & 5.70 & 4.21 & 2.49 & 21.21 & 9.09 \\
\hline $\mathbf{1 0}$ & BCT-10 & 6.47 & 4.16 & 2.89 & 23.41 & 6.86 \\
\hline $\mathbf{1 1}$ & BCT-11 & 5.24 & 4.11 & 3.92 & 25.08 & 4.38 \\
\hline $\mathbf{1 2}$ & BCT-12 & 6.66 & 4.28 & 3.40 & 21.17 & 6.29 \\
\hline $\mathbf{1 3}$ & BCT-13 & 6.02 & 4.18 & 4.33 & 18.53 & 6.03 \\
\hline $\mathbf{1 4}$ & BCT-14 & 7.23 & 4.33 & 1.75 & 15.67 & 6.80 \\
\hline $\mathbf{1 5}$ & BCT-15 & 7.29 & 4.24 & 4.65 & 17.00 & 2.95 \\
\hline $\mathbf{1 6}$ & BCT-16 & 7.17 & 4.01 & 3.56 & 18.79 & 6.30 \\
\hline $\mathbf{1 7}$ & BCT-17 & 5.96 & 3.99 & 1.92 & 21.43 & 4.92 \\
\hline $\mathbf{1 8}$ & BCT-18 & 6.80 & 3.95 & 4.60 & 19.12 & 6.04 \\
\hline $\mathbf{1 9}$ & BCT-19 & 7.04 & 4.17 & 3.68 & 18.34 & 5.92 \\
\hline $\mathbf{2 0}$ & BCT-20 & 6.45 & 4.12 & 5.89 & 20.06 & 5.29 \\
\hline $\mathbf{2 1}$ & BCT-21 & 6.18 & 4.20 & 4.06 & 18.55 & 3.36 \\
\hline $\mathbf{2 2}$ & BCT-22 & 6.11 & 3.93 & 3.89 & 22.43 & 6.11 \\
\hline $\mathbf{2 3}$ & BCT-23 & 5.04 & 4.10 & 4.39 & 15.24 & 5.26 \\
\hline $\mathbf{2 4}$ & BCT-24 & 6.75 & 4.16 & 6.20 & 21.51 & 7.06 \\
\hline $\mathbf{2 5}$ & BCT-25 & 7.14 & 4.34 & 2.99 & 19.51 & 6.22 \\
\hline $\mathbf{2 6}$ & BCT-26 & 6.91 & 4.12 & 5.36 & 18.35 & 6.40 \\
\hline $\mathbf{2 7}$ & BCT-27 & 8.02 & 4.29 & 4.55 & 15.89 & 5.80 \\
\hline $\mathbf{2 8}$ & BCT-28 & 6.50 & 4.14 & 4.80 & 21.70 & 5.20 \\
\hline $\mathbf{2 9}$ & BCT-29 & 7.06 & 4.21 & 3.71 & 19.00 & 5.91 \\
\hline $\mathbf{3 0}$ & BCT-30 & 6.36 & 4.04 & 4.11 & 18.32 & 4.61 \\
\hline & S.Em \pm & 0.09 & 0.09 & 0.04 & 0.31 & 0.04 \\
\hline & CD 0.05$)$ & 0.25 & 0.25 & 0.12 & 0.91 & 0.12 \\
\hline & CV \% & 1.90 & 2.98 & 1.58 & 2.18 & 0.99 \\
\hline & & & & & & \\
\hline
\end{tabular}

This was an agreement with the findings of Nainwal et al., (1992) and Audrius et al., (2009). Ascorbic acid content was significantly higher in BCT-3 (34.97 $\mathrm{mg} / 100 \mathrm{~g}$ ) and the lowest ascorbic acid content was observed in BCT-23 (15.24 $\mathrm{mg} / 100 \mathrm{~g})$. This was in agreement with the findings of Shivanand (2008) and Renuka et al., (2014). Lycopene content of the fruit varied significantly among all the genotypes, the lycopene content was found maximum in BCT-6 (10.14 mg/100g) and the minimum 
was observed in BCT-3 (2.11 mg/100g). The present findings are acknowledged by the results supported by Renuka et al., (2014) in cherry tomato.

In the present study, BCT-27, BCT-14 and BCT-10 as BCT-3, BCT-6 and ВCT-24 are found best for quality concerned. And BCT-8 and BCT-29 were found best for yield. Investigations on suitability of different genotypes for different seasons may be carried out. Agronomic practices can be standardized for the best performed genotypes and promising genotypes can be screened for biotic and abiotic stresses.

\section{References}

A.O.A.C. 2004. Official Methods of Analysis; Association of Official Analytical Chemist, $13^{\text {th }}$ Ed. Washington DC.

Anonymous, 2009a. Botanical classification of cherry tomato. (www.lose-weightwithus.com/cherry tomato-nutrition. html).

Anonymous, 2009b. Cherry tomato nutritional information; USDA National Nutritional Database for Standard Reference. (www.lose-weightwithus.com/cherry tomato-nutrition. html).

Anonymous. 1984. Official Methods of Analysis. ED. Sioney Williams, Association of Official Analytical Chemists, Virginia, $14^{\text {th }}$ Edition. pp. 423-462.

Arun, J. Amit, V. and Thakur, M. C. 2004. Studied on genetic variability, correlation and path analysis for yield physic-chemical traits in tomato (Lycopersicon esculentum Mill.). Prog. Hort., 36(1): 51-58.

Audrius, R., Rasa, K., Ceslovas, B. and Pranas, V. 2009. Nutrition quality of different tomto cultivars. ZemdirbysteAgriculture, 96(3): 67-75.
Berry, S. Z., Uddin, M. R., Gould, W.A., Bisges, A. D. and Dyer, G. D. 1988. Stability in fruit yield, soluble solids and citric acid of eight machine harvested processing tomato cultivars in Northern Ohio. J. American. Soc. Hort. Sci., 113(3): 604-608.

Jackson, M. L. 1973. Soil Chemical Analysis. Prentice Hall of India Pvt. Ltd., New Delhi.

John. R. S, Judith, A. A. and Robert. A. S. 2005. Cherry tomato breeding lines with high $\beta$-carotene content, Hort, Sci., 40(5): 1569-1570.

Madan, S., Rana, M. K. and Munjal, R. 2011. Estimation of quality parameters invegetable. In: Physico-Biochemistry and Biotechnology of Vegetable crops (Rd.: Rana, M.K.). New India Publishing Agency, Pritam Pura, New Delhi (India). 461-482.

Nainwal, N. C, Jaiswal, R. C, Kumar, S. 1992. Suitability of tomato (Lycopersicon esculentum Mill) cultivars for juice, ketchup and chutney making. Prog. Hort., 24(1- 2): 70- 73.

Renuka, D. M., Sadashiva, A. T., Kavita, B. T., Vijendrakumar, R. C. and Hanumanthiah, M. R. 2014. Evaluation of cherry tomato lines (Solanum lycopersicum var. cerasiforme) for growyh, yield and quality traits. Plant Archives, 14(1): 151-154

Shivanand. V. H. 2008. Evaluation of tomato (Lycopersicon esculentum Mill.) hybrids under Eastern dry zone of Karnataka, M.Sc. Thesis, Univ. Agril. Sci., GKVK, Bangalore.

Shoba, N. and Arumugam, R. 1991. Evaluation of quality attributes in inter varietal crosses of tomato. South Indian Hort., 39 (6): 350-352.

Sucheta. S. M. S., Dhaliwal and Cheema, D. S. 2004. Evaluation of tomato hybrids for quality attributes. Harayana J. Hort. Sci., 33(3-4): 305-306. 
How to cite this article:

Najeema M. H., Revanappa, H. P. Hadimani and Biradar I. B. 2018. Evaluation of Cherry Tomato (Solanum lycopersicum var. cerasiforme) Genotypes for Yield and Quality Traits. Int.J.Curr.Microbiol.App.Sci. 7(06): 2433-2439. doi: https://doi.org/10.20546/ijcmas.2018.706.289 